\title{
Using side flow jets as a scour countermeasure downstream of a sluice gate
}

\author{
Mohamed S. Abdelmoaty and Mahmoud Zayed*
}

\begin{abstract}
Background: Local scour is one of the main problems affecting the stability and operation of control hydraulic structures. Many techniques were used to control the resulting scour. In the recent study, a new technique was used to control local scour downstream single-gate hydraulic regulator by using side flow jets. This study aimed to demonstrate the effect of side jets at different angles on the local scour parameters (depth, length, and volume) and energy dissipation in the downstream hydraulic regulator.

Results: A physical model was used to represent the open channel, regulator, and the side jets with different angles. Five flow discharges, four jet angles, and three gate openings were applied through the experiment. The experiment results showed that the presence of side jets had a remarkable effect on the parameters of the local scour hole and energy dissipation. They dissipated more energy of hydraulic jump than in the absence of jets, and consequently, scour hole dimensions were significantly reduced. Regression analysis was used to deduce equations that can predict the development of local scour downstream sluice gate considering the inclination angle of side flow jets under different flow conditions.
\end{abstract}

Conclusions: Side flow jets can be used as scour reducer techniques with the advantages of eliminating the jet clog produced from sediments and suspended solids.

Keywords: Local scour, Energy dissipation, Side flow jets, Sluice gate, Physical model, Free flow

\section{Background}

The sluice gates are frequently attached to regulators with the function of controlling, measuring flow rate, and regulating water levels in irrigation canals. Various researchers have studied the flow through sluice gates [1-7]. When the flow under the gate acts as an orifice flow forming a flow jet, the high velocity of the jet may cause excessive local shear stress and result in local scour over an erodible bed. Local scour can gradually damage the bed material, which eventually leads to structural failures. Therefore, scour process downstream gates have been extensively investigated [8-16]. Dey and Sarkar [17] studied the scouring process and profiles in non-cohesive

\footnotetext{
*Correspondence: mahmoudzayed13@yahoo.com:

mahmoud_zayed@nwrc.gov.eg

Channel Maintenance Research Institute, National Water Research Center, Kalubia 13621, Egypt
}

sediment downstream of a sluice gate with submerged horizontal jet. The scour depth was a function of sediment gradation of non-uniform sediments. The equilibrium scour depth increased with the densimetric Froude number. Also, the formula of equilibrium scour of maximum depth has been empirically produced. Negm et al. [18] experimentally investigated the scour patterns due to the gate operation of multi-events regulators under submerged flow conditions. The results concluded that the maximum scour depth is affected by the pattern of bottom velocity, gate operation, type of gates, submergence ratio, and Froude numbers at vena contract. Sarkar and Dey [19], and Aamir and Ahmad [20] presented a comprehensive review of local scour caused by jets. Aamir and Ahmed [21] experimentally measured local scour developed by smooth and rough aprons under wall jets. The study recommended the use of roughness over the apron to reduce scour caused by wall jets. Aamir and 
Ahmed [22] analyzed laboratory data of scour development due to a two-dimensional horizontal jet that moved over rigid rough apron. In addition, the measured depths of scour were compared with those predicted by different equations. Furthermore, Aamir and Ahmed [23] suggested a relationship to determine downstream scour depth for an apron under wall jets. Rostamy et al. [24] used a laser Doppler anemometry (LDA) to report the turbulence characteristics for both rough and smooth surface of wall jets. Their study results concluded that rough surface modified in the inner layer magnitudes and shape of the profiles of Reynolds stress. Kartal and Emiroglu [25] studied a local scour developed under jet of different nozzle diameters with plats. The experimental results proposed scour equations to predict depth of maximum scour, bridge height, and length of scour hole. Karbasi and Azamathulla [26] applied different soft-computing techniques to determine the maximum depth of scour hole downstream of sluice gate and the study provided prediction accuracy for the established scour depth relationships. Aamir and Ahmed [27] used an artificial neural network as well as adaptive neuro-fuzzy interference system models to estimate scour depth due to submerged wall jets.

Specifically, the roughness elements increase flow turbulence through the hydraulic jump and consequently reduce the length of the jump. The main function of energy dissipation is to protect the downstream channel bed from scouring. Appurtenances as end sills, baffle, and chute blocks within the stilling basin are frequently used to dissipate the excess energy in the high velocity, increase turbulence and the hydraulic jump efficiency, control the bed scour, and reduce the stilling basin length [28], and thereby, it may be possible to reduce the cost of protection works. There are several studies available in the literature on energy dissipation and local scour mitigation using such appurtenances [29-34]. Hamidifar et al. [35] used a single bed sill as a countermeasure to investigate the scour reduction downstream of the apron and to assess its effectiveness at different distances from the apron end. The results showed that the maximum scour reduced up to $95 \%$ downstream of the apron. It was illustrated also at various locations and heights; the scour profiles were different for the sills. To predict the scour hole profile, a regression-based equation has been proposed. Mesbahi et al. [36] predicted the depth of local scour by applying gene expression programming downstream stilling basins. Abdallah [37] examined the effects of end sills of different shapes and different heights on the scour dip downstream of the apron. The findings showed the sill height was more effective than the shape on the scour hole. Elnikhely [38] has experimentally studied scour hole dimensions downstream of the spillway at various arrangements, lengths, and diameters of cylinder blocks under different flow conditions. The experimental data were employed to develop simple empirical relations to predict the scour hole parameters downstream of the spillway. Chahartaghi et al. [39] conducted experiments to study the effects of three geometry blocks, including trihedral, semicircle, and trapezoidal shapes using a baffle chute with a 2:1 slope on local scour downstream of spillways. Tuna and Emiroglu [40] studied the dynamics of local scour due to step geometry downstream of stepped chutes. Step heights, chute angles, stilling basin sill heights, and tailwater depths were investigated for different flow conditions. The equilibrium depth of scour was affected by the geometry of the step, decreased with the increase in step height, and increased by the chute angle and discharge.

It is possible to control the hydraulic jump using a jet instead of the usual appurtenances. Using jets as energy dissipators to control a hydraulic jump has been investigated [41-46]. Varol et al. [46] studied the characteristics of hydraulic jump controlled by jet with different flow rates. The length of the jump decreased with increasing the flow rate of the jet. Also, the jump with a water jet resulted in more energy losses compared to the free hydraulic jump. Aboulatta [47] investigated the effect of floor jets on the characteristics of free and submerged jump.

Consequently, the utilization of jets to dissipate energy can be a scour countermeasure to the downstream hydraulic structure. Aboulatta [48] experimentally investigated the impact of the floor jets on scouring development downstream of an apron of a radial stilling basin. For different relative upstream heads, the maximum depth of scour was measured at different time intervals for a flat floor with and without jets. In particular, floor jets significantly reduced the scour depth, length, and volume. The study also proposed equations to predict the depth of scouring developed for both the flat floor and the flat floor with jets. Aboulatta and Kamel [49] studied the protection of the scouring process using different methods including floor jets and riprap bed. The results of the study concluded that the scour depth and volume were severely decreased using floor jets, and at almost the same effects were detected for riprap bed without floor jets. In addition, the study recommended using a riprap protection layer only at Froude numbers less than 4 for structure operation and using floor jets for Froude numbers $>4$.

A lake of knowledge exists about using side wall jets with various inclination angles from the side wall to determine scour development and energy dissipation. Most of the available reviews on controlling scour by jets relate to the study of scour processes caused by floor jets. 
Despite this, this paper investigates the effects of using the side flow jets under different angles, and flow conditions to primarily control the scour process downstream sluice gate.

\section{Methods}

A recirculating flume located within the Channel Maintenance Research Institute, National Water Research Center, was used to conduct the tests. The experiments were performed in a 16.22-m-long, 0.60-m-wide, and 0.42-m-deep channel with a trapezoidal concrete shape and 1:1 side slope. The flume inlet was $4.52 \mathrm{~m}$ long, $1.16 \mathrm{~m}$ deep, and $1.63 \mathrm{~m}$ wide with two vertical walls. And, the outlet part was $0.96 \mathrm{~m}$ long, $1.21 \mathrm{~m}$ deep, and $1.63 \mathrm{~m}$ wide. Two 8-inch pipes were used to collect water from the outlet basin to supply an underground reservoir. A 40-cm-width single sluice gate regulator was constructed vertically with horizontal edge and with three openings. Two side jets of $2.0 \mathrm{~cm}$ diameter were installed with positive angles $\theta=150^{\circ}, 120^{\circ}$, and $90^{\circ}$ (perpendicular to the direction of flow), and one jet was arranged for each side wall (Fig. 1). The side flow jets were fixed to the side walls just upstream the bed level at a distance of $X_{\mathrm{j}} / X_{\mathrm{a}}=0.41$ downstream the gate, as $X_{\mathrm{j}}$ is distance of jet from the gate and $X_{\mathrm{a}}$ is the length of apron. They worked under the main differences between upstream and downstream gate levels. The soil basin was constructed downstream the regulator with dimensions of $160 \times 60 \mathrm{~cm}$. The basin was filled with the soil in which was leveled to bed level before each run. A drainage system was installed to drain excess water before recording sand levels at the end of each run. The median size of the experiment bed material was $d_{50}=0.50 \mathrm{~mm}$.

Five discharges were selected during the tests $(Q=32$, $34,36,38$, and $40 \mathrm{Ls}^{-1}$ ), a sluice gate with three openings of $G=6.0,6.5$, and $7.0 \mathrm{~cm}$, resulting in a jet velocity to the velocity upstream the hydraulic jump $V_{\mathrm{j}} / V_{1}$ between 0.49 and 0.71 . Three jet angles of $\theta=150^{\circ}$, $120^{\circ}$, and 90 (perpendicular to the flow direction) were tested to examine the effects of side jet angles on the scour hole dimensions and energy loss compared to without jet case. For each run, the resultant scour hole was surveyed and the main scour parameters were determined after $100 \mathrm{~min}$. Table 1 shows the experimental conditions and the ranges of tested parameter.

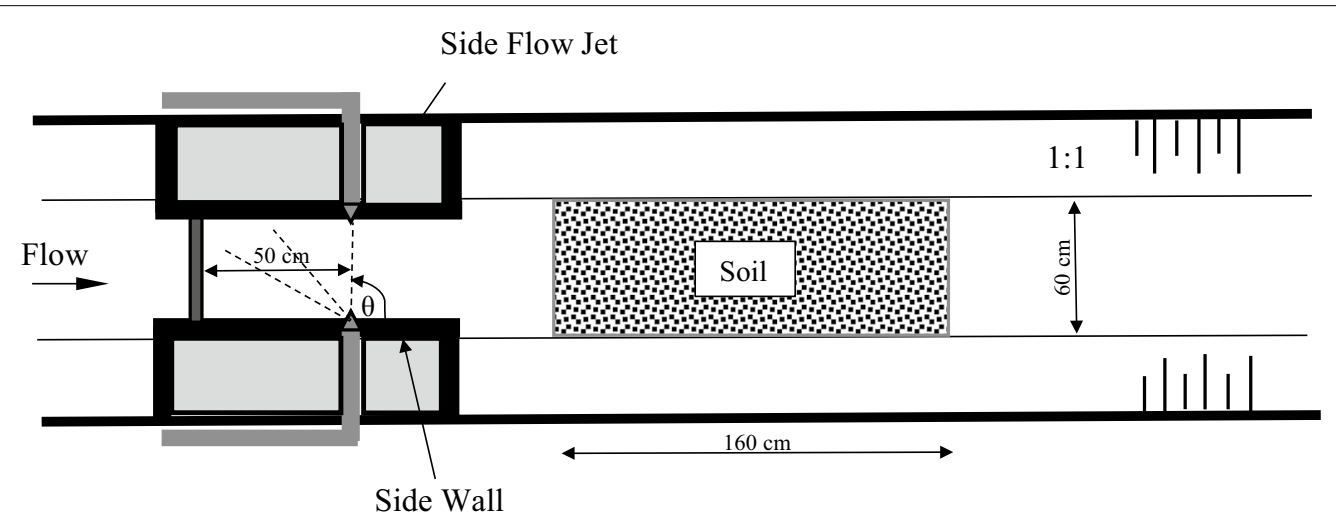

(a)

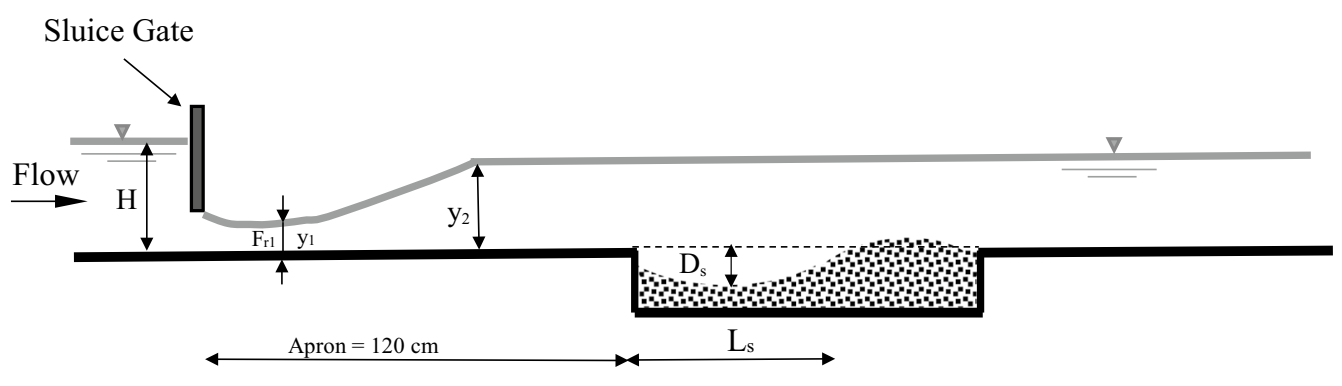

(b)

Fig. 1 Sketch of the experimental setup a plan and $\mathbf{b}$ side view 
Table 1 Overview of the test conditions and parameter ranges

\begin{tabular}{ll}
\hline Parameter & Range \\
\hline Discharge $Q\left(\mathrm{Ls}^{-1}\right)$ & $32,34,36,38,40$ \\
Angle of flow jet from wall $\theta\left(^{\circ}\right)$ & $150,120,90$, without jet \\
Sluice gate opening $G(\mathrm{~cm})$ & $6,6.5,7$ \\
Froude number upstream of the jump $F_{r 1}$ & $2.31-3.71$ \\
Froude number downstream of the jump $F_{r 2}$ & $0.31-0.41$ \\
Flow depth upstream the sluice gate $H(\mathrm{~cm})$ & $26.6-37.07$ \\
Jet velocity to velocity upstream the jump $V_{j} V_{1}$ & $0.49-0.71$, without jet \\
Flow depth upstream of the jump $y_{1}(\mathrm{~cm})$ & $4.2-4.9$ \\
Flow depth downstream of the jump $y_{2}(\mathrm{~cm})$ & $17.07-19.54$ \\
Maximum scour depth $D_{s}(\mathrm{~cm})$ & $5-7.2$ \\
Length of scour $L_{s}\left(\mathrm{~cm}^{\circ}\right.$ & $65-113.5$ \\
Volume of scour $V_{s}\left(\mathrm{~cm}^{3}\right)$ & $13,331-38,088$ \\
\hline
\end{tabular}

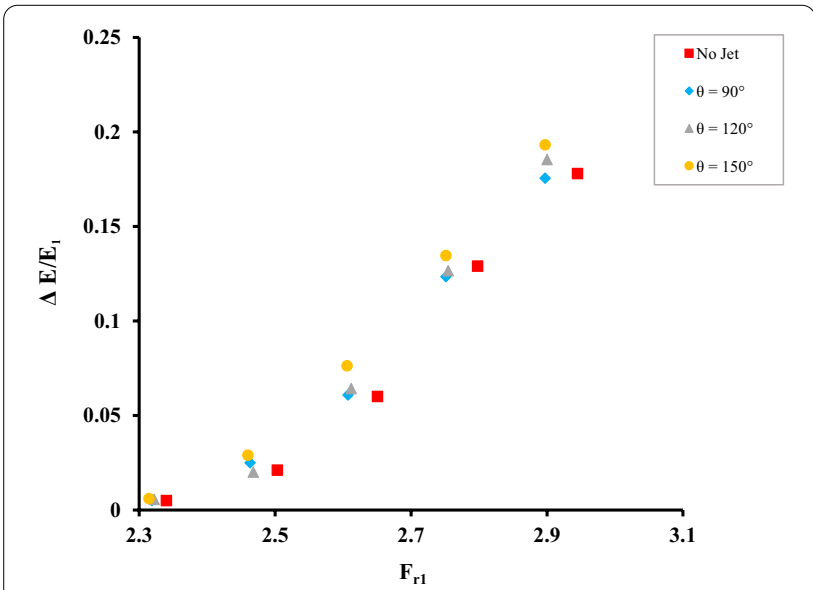

Fig. 2 Relative energy dissipation $\Delta E / E_{1}$ versus $F_{r 1}$ for the tested flow jet arrangements at gate opening $G=7 \mathrm{~cm}$

\section{Results}

\subsection{Energy dissipation}

The variations in the relative energy dissipation $\Delta E / E_{1}$ with Froude number upstream of the jump $F_{r 1}$ for side jet positive angles of $\theta=90^{\circ}-150^{\circ}$ and without side jet are shown in Fig. 2. The relative energy dissipation $\Delta E / E_{1}$ between upstream and downstream the hydraulic jump relative to the upstream energy can be computed using the form:

$$
\Delta E=E_{1}-E_{2}=\left(y_{1}+\frac{V_{1}^{2}}{2 g}\right)-\left(y_{2}+\frac{V_{2}^{2}}{2 g}\right)
$$

Then, the relative energy loss is expressed by Eq. 2

$$
\frac{\Delta E}{E_{1}}=\frac{E_{1}-E_{2}}{E_{1}}
$$

where $\Delta \mathrm{E}$ is the energy dissipation, $E_{1}, y_{1}$, and $V_{1}$ are the energy head, water depth, and velocity upstream the hydraulic jump, respectively, $E_{2}, y_{2}$, and $V_{2}$ are the energy head, water depth, and velocity downstream the hydraulic jump, and $g$ is the gravitational acceleration.

\subsection{Scour hole dimensions}

\subsubsection{Effect of side jet angles}

The relative terms of $D_{\mathrm{s}} / H, L_{\mathrm{s}} / H$, and $V_{\mathrm{s}} / H^{3}$ were investigated for different side jet positive angles of $\theta=150^{\circ}, 120^{\circ}$, and $90^{\circ}$ (perpendicular to the flow direction) and without side jet in the range of $F_{r 1} \approx 2.90-3.71$ at $G=6 \mathrm{~cm}$ to examine the effect of side jet angles on the scour hole dimensions. The relationship between the relative term of $D_{\mathrm{s}} / H$ and different $F_{\mathrm{r} 1}$ for the tested jet angles is shown in Fig. 3a with a constant of all other parameters. The relationship between dimensionless term $L_{\mathrm{s}} / H$ and $F_{\mathrm{r} 1}$ at the tested jet angles is illustrated in Fig. 3b. In Fig. 3b, it is evident that the $L_{\mathrm{s}} / H$ values increase with $F_{\mathrm{r} 1}$ for all tested angles. Figure $3 \mathrm{c}$ demonstrates the effects of jet angles on the scour volume $V_{s}$. According to this figure, the angle of jet affects the relative scour volume. As $\theta$ increases, the relative term $V_{s} / H^{3}$ decreases in all the tested conditions of flow. Additionally, when $F_{\mathrm{r} 1}$ reduces, the term $V_{\mathrm{s}} / H^{3}$ value increases.

\section{Discussion}

\subsection{Energy dissipation analysis}

Figure 2 demonstrates that relative energy dissipation increases with increasing side jet angles. The largest $\Delta E / E_{1}$ values occur at $\theta=150^{\circ}$ for a constant Froude number and inclination of angle. Increasing the side jet angle results in more force and resistance against the incoming supercritical flow. Therefore, the use of side jets arrangement can dissipate higher energy for hydraulic jump as compared to the case of without jets and this is consistent with the observations of El Sayed [45]. Figure 2 also displays that $\Delta E / E_{1}$ increases with increasing $F_{r 1}$ at a constant angle.

\subsection{Side jet angles analysis}

Figure $3 \mathrm{a}$ displays the component value of $D_{\mathrm{s}} / H$ decreases with increasing $F_{r 1}$ for all test configurations, as maximum scour depth $D_{\mathrm{s}}$ value was less than the value of flow depth upstream the sluice gate $H$ in the term $D_{\mathrm{s}} / H$ during the tests. Therefore, the maximum scour depth parameter $D_{\mathrm{s}}$ increases only with $F_{r 1}$, since a higher energy of $F_{r 1}$ results in an increase in scour hole parameters. In addition, increasing $\theta$ reduces the $D_{\mathrm{s}} / H$ value for all arrangements indicating 


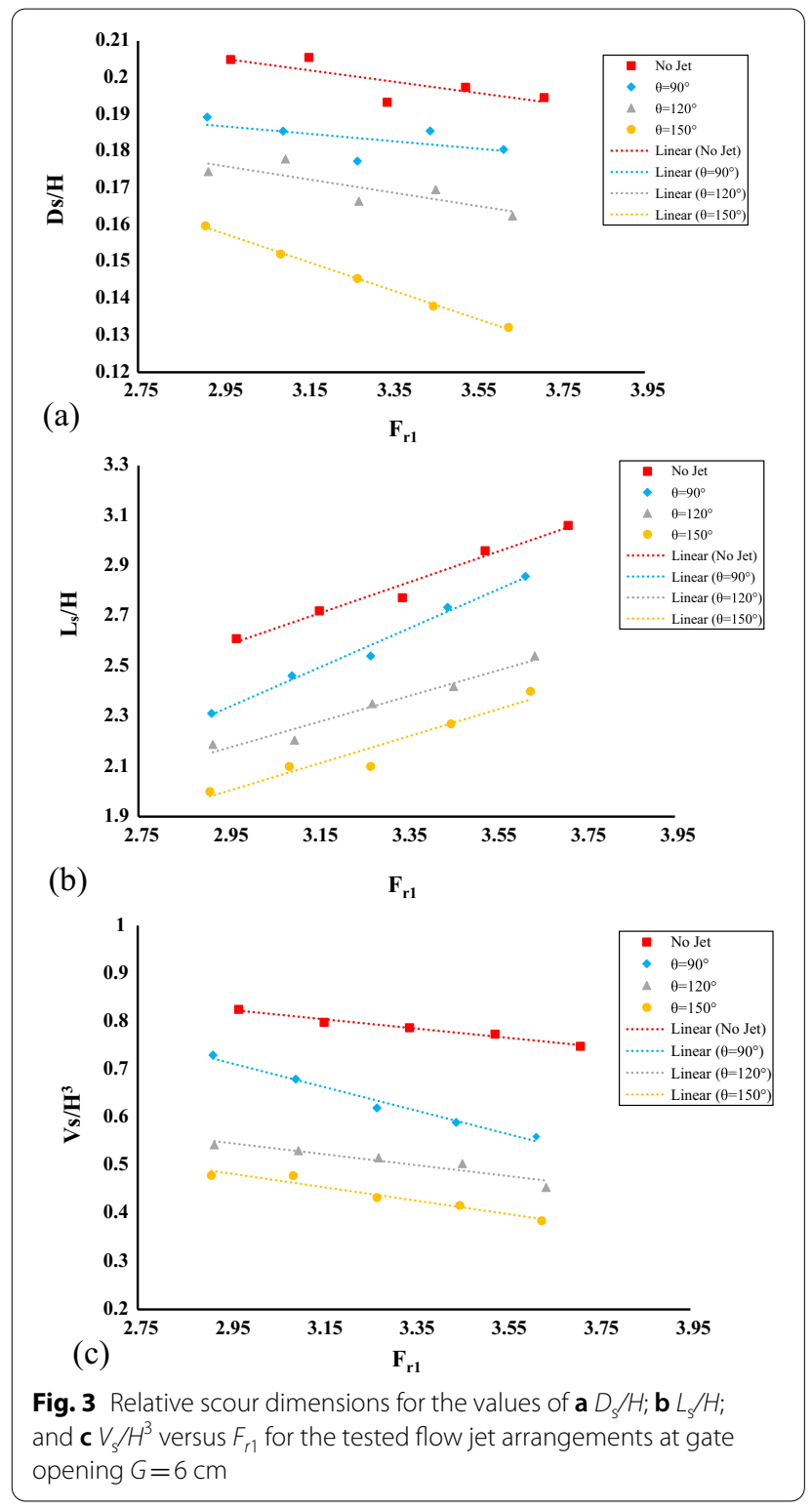

that the maximum scour depth reduces as the jet angles increase. For average Froude numbers, using a jet with $\theta=90^{\circ}, 120^{\circ}$, and $150^{\circ}$ decreases the scour depth $D_{\mathrm{s}}$ by approximately 11,16 , and $25 \%$, respectively, compared to without a jet. The presence of side jets can dissipate more energy [45], and hence, the reduction in scour depth occurs. In particular, the flow of side jet against the incoming supercritical flow increases with the jet angle, and hence the energy dissipation increases, which results in reducing the scour hole parameters. In contrast, $\theta$ affects the maximum scour depth.

Given the same flow conditions, larger $\theta$ results in smaller $L_{\mathrm{s}} / H$ values (Fig. $3 \mathrm{~b}$ ). Hence, the scour length $L_{\mathrm{s}}$ decreases with increasing jet angles. Specifically, the average scour length reductions are approximately 9,13 , and $15 \%$ for jet angles of $\theta=90^{\circ}, 120^{\circ}$, and $150^{\circ}$, respectively, compared to without jet case. Increasing jet angles $\theta$, against the incoming flow under gate, results in more energy dissipation, thus reducing hydraulic jump length, leading to a smaller scour length.

The results show that increasing $\theta$ can minimize the relative term $V_{\mathrm{s}} / H^{3}$ at all tested flow conditions (Fig. 3c). Specifically, the volume of a scour hole $V_{\mathrm{s}}$ decreases by 19,31 , and $40 \%$ compared to the case of no side jet for $\theta=90^{\circ}, 120^{\circ}$, and $150^{\circ}$, respectively. Furthermore, the minimum value of $F_{r 1}$ produces the maximum term $V_{\mathrm{s}} / H^{3}$ value, as $V_{\mathrm{s}}$ value was less than $H^{3}$ value in the term $V_{\mathrm{s}} / H^{3}$, and the maximum volume of scour $V_{\mathrm{s}}$ only occurs with larger $F_{r 1}$ for each angle. As previously demonstrated, increasing $\theta$ dissipates more flow energy, and hence $V_{\mathrm{s}}$ decreases because the depth and length of scour become smaller downstream of the apron. In summary, it should be noted that the side flow jets can significantly be considered as a scour countermeasure especially with angles against the incoming flow. Furthermore, side jets may have more utility in eliminating the clog of jets that result from suspended solids and sediments, and are also simpler in design compared to floor flow jets.

\subsubsection{Design equation for scour hole dimensions}

Experimental data with dimensionless terms were employed to propose three equations to predict local scour parameters $\left(D_{s}, L_{s}\right.$, and $\left.V_{s}\right)$ with the presence of side flow jets. With regard to regression analysis, the effective variables on local scour were used and the following equations were deduced:

$$
\begin{aligned}
\frac{D_{\mathrm{s}}}{H}= & 0.026 \cos \theta+0.047 F_{r 1}+0.945 \frac{G}{H}-0.232 F_{r 2}-0.061 \\
\frac{L_{\mathrm{s}}}{H}= & 0.252 \cos \theta+2.519 F_{r 2}+14.740 \frac{G}{H} \\
& +1.107 F_{r 1}+1.042 \frac{V_{j}}{V_{1}}-5.289 \\
\frac{V_{\mathrm{s}}}{H^{3}}= & 0.353 \cos \theta+1.038 F_{r 2}+4.094 \frac{G}{H}+0.531 \frac{V_{j}}{V_{1}}-0.711
\end{aligned}
$$

where $G=$ sluice gate opening; $H=$ flow depth upstream the sluice gate; and $F_{r 2}=$ Froude number downstream of the jump.

Parameters that affect the scour hole in Eqs. 3-5 have $p$-values $<0.0001$ indicating a significant impacts on the local scour. Theses equations are valid for $90^{\circ} \leq \theta \leq 150^{\circ}$, $0.49 \leq V_{\mathrm{j}} / V_{1} \leq 0.71, \quad 0.16 \leq G / H \leq 0.26, \quad 2.31 \leq F_{r 1} \leq 3.71$, 

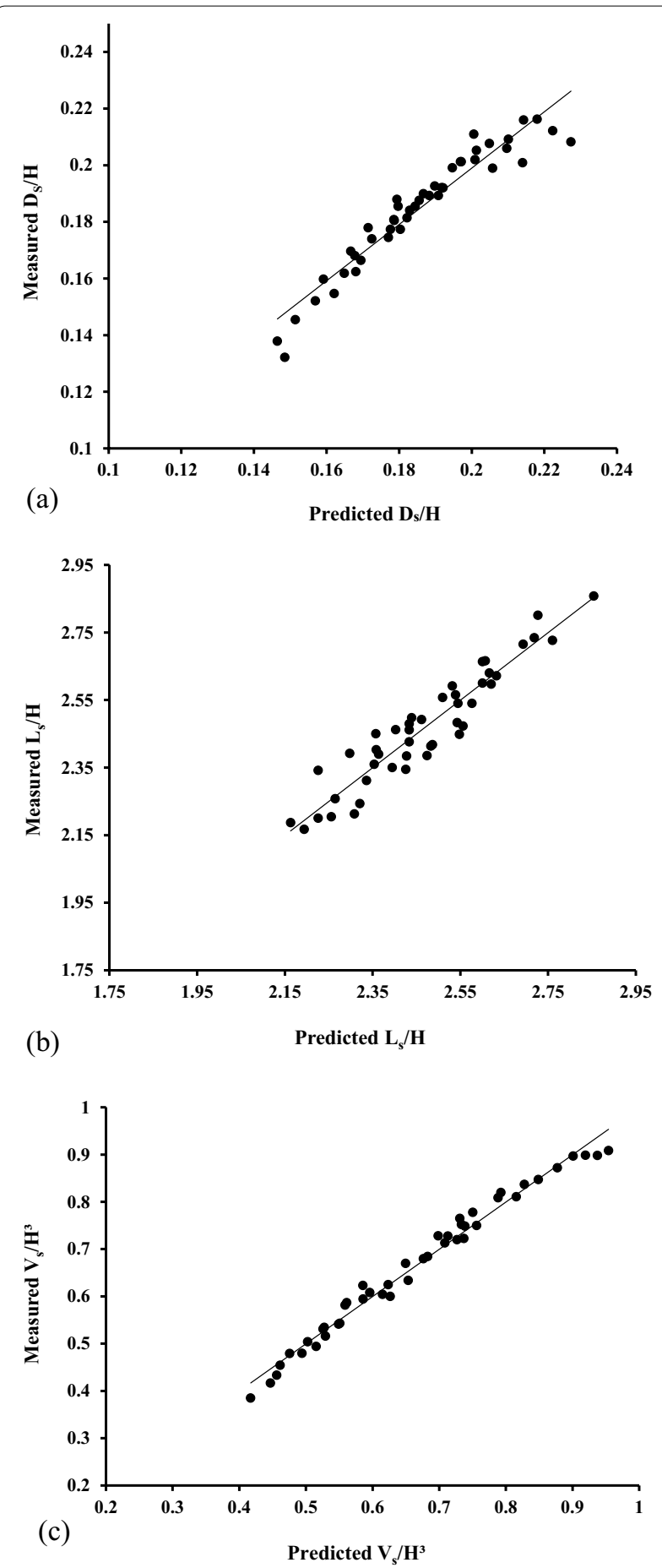

Fig. 4 Comparison between the measured relative scour dimension values and those predicted by a Eq. (3); b Eq. (4); and c Eq. (5)

and $0.31 \leq F_{r 2} \leq 0.41$. Figure 4 shows the comparison between the values of the measured relative local scour dimensions $\left(D_{\mathrm{s}} / H, L_{\mathrm{s}} / H, V_{\mathrm{s}} / H^{3}\right)$ and the predicted values by Eqs. 3-5, respectively. These figures illustrate that the predicted values of $D_{\mathrm{s}} / H, L_{\mathrm{s}} / H$, and $V_{\mathrm{s}} / H^{3}$ are consistent with the measured values with $R^{2}=0.92,0.89$, and 0.98 , respectively.

\section{Conclusions}

This paper presents an experimental investigation to allow analysis of side flow jets as scour countermeasure and energy dissipator. Side flow jets were examined for a range of positive angles between $90^{\circ}$ and $150^{\circ}$ at different flow conditions and compared to the reference case of without jet to define the scour evolution and energy dissipation. The findings imply the following.

- Side flow jets had a notable impact on the local scour hole parameters and energy dissipation. They increased the energy dissipation, thus reducing the depth, length, and volume of scour hole.

- The use of side flow jets reduced the scour hole by approximately 11, 16, and $25 \%$ for scour depth, 9, 13 , and $15 \%$ for scour length, and 19, 31, and $40 \%$ for scour volume for jet angles of $\theta=90^{\circ}, 120^{\circ}$, and $150^{\circ}$, respectively, compared to without jet case due to the increased energy dissipation.

- Three empirical equations have been proposed to predict the depth, length, and volume of local scour resulting from the presence of side flow jets.

In fact, side jets may have more advantages about eliminating the jets clog that developed from sediments and suspended solids and are also simpler in design compared to the floor flow jets. For further studies, it is essential to investigate the scour processes downstream multi-gate regulator for different side flow jet positions under various flow conditions. Furthermore, considering the effects on vena contracta could be useful with possible consequences for the performance of the sluice gate discharge coefficients.

\section{Abbreviations}

$D_{s}$ : Depth of maximum scour; $d_{50}$ : Median size of mobile bed; $E_{1}$ : Energy head upstream of the hydraulic jump; $E_{2}$ : Energy head downstream of the hydraulic jump; $F_{r 1}$ : Froude number upstream of the jump; $F_{r 2}$ : Froude number downstream of the jump; G: Sluice gate opening; $g$ : Gravitational acceleration; $H$ : Flow depth upstream the sluice gate; $L_{s}$ : Length of scour; $Q$ : Flow discharge; $V_{j}$ : Velocity of flow jet; $V_{s}$ : Volume of scour hole; $V_{1}:$ Velocity upstream of the hydraulic jump; $V_{2}$ : Velocity downstream of the hydraulic jump; $X_{a}$ : Length of apron; $X_{j}$ : Distance of jet from the gate; $y_{1}$ : Flow depth upstream of the hydraulic jump; $y_{2}$ : Flow depth downstream of the hydraulic jump; $\theta$ : Inclination positive angle of flow jet from wall; $\Delta E$ : Energy dissipation between upstream and downstream the hydraulic jump. 


\section{Acknowledgements}

The authors appreciatively acknowledge the support of Channel Maintenance Research Institute (CMRI), the National Water Research Center (NWRC), Egypt, for facilitating experimental setup.

\section{Authors' contributions}

MSA designed the study and carried out research. MZ wrote manuscript. All authors have read and approved the manuscript.

\section{Funding}

None.

\section{Availability of data and materials}

The datasets used and/or analyzed during the current study are available from the corresponding author on reasonable request.

\section{Declarations}

Ethics approval and consent to participate

Not applicable.

\section{Consent for publication}

Not applicable.

\section{Competing interests}

The authors declare that they have no competing interests.

Received: 17 September 2021 Accepted: 4 December 2021

Published online: 15 December 2021

\section{References}

1. Roth A, Hager WH (1999) Underflow of standard sluice gate. Exp Fluids 27:339-350

2. Ferro V (2000) Simultaneous flow over and under a gate. J Irrig Drain Eng 126(3):190-193. https://doi.org/10.1061/(ASCE)0733-9437(2000)126: 3(190)

3. Lin CH, Yen JF, Tsai CT (2002) Influence of sluice gate contraction coefficient on distinguishing condition. J Irrig Drain Eng 128(4):249-252. https://doi.org/10.1061/(ASCE)0733-9437(2002)128:4(249)

4. Sepûlveda C, Gómez M, Rodellar J (2009) Benchmark of discharge calibration methods for submerged sluice gates. J Irrig Drain Eng 135(5):676-682

5. Oskuyi NN, Salmasi F (2012) Vertical sluice gate discharge coefficient. J Civ Eng 23:108-114

6. Wu S, Rajaratnam N (2015) Solutions to rectangular sluice gate flow problems. J Irrig Drain Eng 141(12):06015003. https://doi.org/10.1061/(ASCE) IR.1943-4774.0000922

7. Silva CO, Rijo M (2017) Flow rate measurements under sluice gates. J Irrig Drain Eng 143(6):06017001. https://doi.org/10.1061/(ASCE)IR.1943-4774. 0001177

8. Uyumaz A (1988) Scour downstream of vertical gate. J Hydraul Eng 114(7):811-816

9. Chatterjee SS, Ghosh SN, Chatterjee M (1994) Local scour due to submerged horizontal jet. J Hydraul Eng 120(8):973-992

10. Balachandar R, Kells JA (1997) Local channel scour in uniformly graded sediments: the time-scale problem. Can J Civ Eng 24(5):799-807

11. Balachandar R, Kells JA (1998) Instantaneous water surface and bed scour profiles using video image analysis. Can J Civ Eng 25(4):662-667

12. Kells JA, Balachandar R, Hagel KP (2001) Effect of grain size on local channel scour below a sluice gate. Can J Civ Eng 28(3):440-451

13. Dey S, Westrich B (2003) Hydraulics of submerged jet subject to change in cohesive bed geometry. J Hydraul Eng 129(1):44-53

14. Sarkar A, Dey S (2005) Scour hole downstream of aprons caused by sluices. In: Proc Inst Civ Eng, Water Management J Lond 158(June):55-64

15. Verma DVS, Goel A (2005) Scour downstream of a sluice gate. ISH J Hydraul Eng 11(3):57-65
16. Melville BW, Lim SY (2014) Scour caused by 2D horizontal jets. J Hydraul Eng 140(2):149-155

17. Dey S, Sarkar A (2006) Scour downstream of an apron due to submerged horizontal jets. J Hydraul Eng 132(3):246-257. https://doi.org/10.1061/ (ASCE)0733-9429(2006)132:3(246)

18. Negm AM, Abdel-Aal GM, Elfiky MM, Mohamed YA (2007) Effect of multi-gates regulators operations on downstream scour pattern under submerged flow conditions. In: Proc 11 th Int water technol conference, (IWTC11), Sharm El-Sheikh, Egypt, pp 735-767

19. Sarkar A, Dey S (2004) Review on local scour due to jets. Int I Sediment Res 19(3):210-238

20. Aamir M, Ahmad Z (2016) Review of literature on local scour under plane turbulent wall jets. Phys Fluids 28(10):105-102. https://doi.org/10.1063/1. 4964659

21. Aamir M, Ahmad Z (2021) Effect of apron roughness on flow characteristics and scour depth under submerged wall jets. Acta Geophys. https:// doi.org/10.1007/s11600-021-00672-9

22. Aamir M, Ahmad Z (2015) Estimation of scour depth downstream of an apron under 2D horizontal jets. In: Proc of HYDRO 2015 international, 20th international conference on hydraulics, water resources and river engineering, Indian Institute of Technology Roorkee, India

23. Aamir M, Ahmad Z (2017) Prediction of local scour depth downstream of an apron under wall jets. In: Garg V, Singh V, Raj V (eds) Development of water resources in India. Water science and technology library, Springer, Cham 75(32), pp 375-385. https://doi.org/10.1007/978-3-319-55125-8_ 32

24. Rostamy N, Bergstrom DJ, Sumner D, Bugg JD (2011) The effect of surface roughness on the turbulence structure of a plane wall jet. Phys Fluids 23:085103. https://doi.org/10.1063/1.3614478

25. Kartal V, Emiroglu ME (2021) Local scour due to water jet from a nozzle with plates. Acta Geophys 69:95-112. https://doi.org/10.1007/ s11600-020-00521-1

26. Karbasi M, Azamathulla HM (2017) Prediction of scour caused by 2D horizontal jets using soft computing techniques. Ain Shams Eng J 8(4):559-570. https://doi.org/10.1016/j.asej.2016.04.001

27. Aamir M, Ahmad Z (2019) Estimation of maximum scour depth downstream of an apron under submerged wall jets. J Hydroinf 21 (4):523-540. https://doi.org/10.2166/hydro.2019.008

28. FEMA (Federal Emergency Management Agency) (2010) Outlet works energy dissipators: best practices for design, construction, problem identification and evaluation, inspection, maintenance, renovation, and repair. Technical Manual, FEMA P-679/ June 2010, U.S

29. Nashat AA (1995) The proper location of floor sill with scour reach downstream of heading-up structure. Bull Faculty Eng Assiut Univ 1995; 23(2)

30. Abdel Razek M, Baghdadi HK (1996) Sill effect on local scour downstream gates. Alexandria Eng J 35(5):C245-C257

31. El-Masry AA, Sarhan TE (2000) Minimization of scour downstream heading-up structure using a single line of angle baffles. Eng Res J Helwan Univ 2000:69

32. El-Gamal MM (2001) Effect of using three-lines of angle baffles on scour downstream heading-up structure. Mansoura Eng J 2001: 26(2)

33. Saleh OK, Negm AM, Ahmed NG (2003) Effect of asymmetric side sill on scour characteristics downstream of sudden expanding stilling basins. In: Al-Azhar engineering 7th international conference, Cairo, Egypt

34. Emiroglu ME, Tuna MC (2011) The effect of tailwater depth on the local scour downstream of stepped-chutes. KSCE J Civ Eng 15(5):907-915

35. Hamidifar H, Nasrabadi M, Omid MH (2018) Using a bed sill as a scour countermeasure downstream of an apron. Ain Shams Eng 9(4):1663-1669

36. Mesbahi M, Talebbeydokhti N, Hosseini SA, Afzali SH (2016) Gene-expression programming to predict the local scour depth at downstream of stilling basins. Scientia Iranica 23(1):102-113. https://doi.org/10.24200/sci. 2016.2101

37. Abdallah MG (1990) Study of local scour for channel bed downstream heading-up structure, M.Sc Thesis, Mansoura Univ, 1990

38. Elnikhely EA (2018) Investigation and analysis of scour downstream of a spillway. Ain Shams Eng J 9(4):2275-2282

39. Chahartaghi KM, Nazari S, Babarsad MS (2020) Investigating the effects of the block geometries and sidewall divergences on the local scour downstream of baffled chute spillways. Adv Civ Eng vol. 2020, Article ID 2978602 
40. Tuna MC, Emiroglu ME (2013) Effect of step geometry on local scour downstream of stepped chutes. Arab J Sci Eng 38(3):579-588

41. France PW (1981) Investigation of a jet-assisted hydraulic jump. J Hydrau Res 19(4):325-337

42. Tople SP, Porey PD, Rangaraju K (1986) Hydraulic jump under the influence of two-dimensional cross jets. J Inst Eng 66(6):277-283

43. Aboulatta N (1994) Radial free jump controlled by Jets downstream low head hydraulic structures. Sci Bull Fac Eng Ain Shams Univ 29(1):79-95

44. Abdelilateef M (1994) Hydraulic jump assisted by cross jets at diverging walls. Civ Eng Res Mag 16:273-286

45. El Sayed W (2006) Effect of side flow on the energy downstream sluice gates, Ph.D Thesis, Al-Azhar University, Cairo, Egypt, 2006

46. Varol F, Cevik E, Yuksel Y (2009) The effect of water jet on the hydraulic jump. In: 13th Int water technol conference, IWTC, Vol. 13, p. 895-910, Hurgada, Egypt
47. Aboulatta N (1990) Hydraulic jump controlled by jets, Ph.D Thesis, Ain Shams University, Cairo, Egypt,1990

48. Aboulatta N (2000) Floor jets as Anti-scour device in radial basin subjected to sheet flow. Sci Bull Fac Eng Ain Shams Univ 35(1):79-95

49. Aboulatta N, Kamel SM (1996) Effect of different ways of protection on scour development. Sci Bull Fac Eng Ain Shams Univ 31(4):127-139

\section{Publisher's Note}

Springer Nature remains neutral with regard to jurisdictional claims in published maps and institutional affiliations.

\section{Submit your manuscript to a SpringerOpen ${ }^{\circ}$ journal and benefit from:}

- Convenient online submission

- Rigorous peer review

- Open access: articles freely available online

- High visibility within the field

- Retaining the copyright to your article

Submit your next manuscript at $\boldsymbol{\nabla}$ springeropen.com 